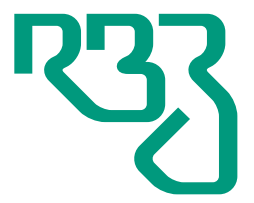

\section{Revista}

Brasileira de

Zootecnia

Brazilian Journal of Animal Science

ISSN 1806-9290

www.rbz.org.br

\title{
Phenotypic diversity between Brazilian fighting cocks and naturalized roosters
}

\author{
Vicente Ibiapina Neto ${ }^{*^{*}}$ (iD, Firmino José Vieira Barbosa ${ }^{2}$ iD, José Elivalto \\ Guimarães Campelo $^{3}$ (iD, José Lindenberg Rocha Sarmento ${ }^{3}$ (D), Natanael \\ Pereira da Silva Santos ${ }^{4}$ (D), Marcos David Figueiredo de Carvalho ${ }^{3}$ (ID \\ ${ }^{1}$ Universidade Federal do Piauí, Programa de Pós-Graduação em Ciência Animal, Teresina, \\ PI, Brasil. \\ ${ }^{2}$ Universidade Estadual do Piauí, Centro de Ciências Agrárias, Teresina, PI, Brasil. \\ ${ }^{3}$ Universidade Federal do Piauí, Departamento de Zootecnia, Teresina, PI, Brasil. \\ ${ }^{4}$ Universidade Federal do Piauí, Campus Professora Cinobelina Elvas, Bom Jesus, PI, Brasil.
}

*Corresponding author:

vicente_ibiapina@hotmail.com

Received: November 1, 2018

Accepted: April 8, 2019

How to cite: Ibiapina Neto, V.; Barbosa, F. J. V.; Campelo, J. E. G.; Sarmento, J. L. R.; Santos, N. P. S. and Carvalho, M. D. F. 2019. Phenotypic diversity between Brazilian fighting cocks and naturalized roosters. Revista Brasileira de Zootecnia 48:e20180271.

https://doi.org/10.1590/rbz4820180271

Copyright: This is an open access article distributed under the terms of the

Creative Commons Attribution License (http://creativecommons.org/licenses/by/4.0/) which permits unrestricted use, distribution, and reproduction in any medium, provided the original work is properly cited.

\begin{abstract}
The present study was carried out to evaluate the phenotypic diversity between fighting cocks; roosters of the naturalized ecotypes Graúna Dourada, Brejeira, Teresina, and Nordestina; roosters of the Sertaneja genetic (synthetic) group; and family-farmed roosters via descriptive and multivariate analyses. The qualitative traits evaluated by descriptive analysis indicated a prevalence of single comb in the Graúna Dourada, Teresina, Nordestina, and Sertaneja ecotypes, whereas the Brejeira ecotype, fighting cocks, and family-farmed roosters have a pea-type comb, which can be viewed as a sign of introgression of the fighting cock in flocks of the region. Dark plumage prevailed across the groups. The quantitative traits subjected to multivariate analysis by clustering criteria placed the four ecotypes and the synthetic type in a single group, the family-farmed animals were allocated to another group, and, lastly, the fighting cocks were placed in a third group. These results were similar to those generated by principal component analysis, which indicated body length, wingspan, and body weight as the traits of greatest variability to discriminate the different groups. It is important to stress the risk of genetic erosion to which naturalized chicken populations are exposed as a consequence of the introgression of fighting cocks in naturalized-chicken rearing facilities.
\end{abstract}

Keywords: cluster analysis, morphometry, multivariate analysis, principal component analysis

\section{Introduction}

In Brazil, chicken considered "naturalized" are descendants of birds that have been introduced in the country since its discovery and colonization. Over time, these animals have undergone natural selection and adapted to the environment, exhibiting original and acquired traits.

The importance of regional birds has grown in the last few years. This is especially true for those from the northeast region of Brazil, which are also important for the selective breeding of flocks that constitute family poultry farming (Clementino et al., 2010). Therefore, the interest in maintaining groups with a defined genetic identity has increased, and conservation programs have thus been implemented. Before this process, however, producers must characterize the variability and potential to guide genetic breeding programs. This step is undertaken in accordance with methodologies proposed by Food and 
Agriculture Organization (FAO, 1981) and Francesch et al. (2011) and works developed by Méndez et al. (2011), based on morphometric measurements.

Information about the extent of genetic diversity in poultry is essential for the development of strategies to preserve and exploit these resources (Zaragoza et al., 2013).

No less important is the risk of genetic erosion to which local populations are exposed, or the extinction of isolated groups of those birds (Riztyan et al., 2011). A situation that may be considered relevant in poultry facilities is the possibility of mating females belonging to family farms to fighting cocks. Both are genetic groups of regional importance, and when the useful lifespan of a fighting cock is over, the animal is incorporated into the breeding grounds of family farms. Because of their aggressiveness, fighting cocks overpower the males of naturalized groups. As a consequence, the genetic constitution of these populations is affected.

Because males remain in breeding facility for a longer period and leave more descendants, they have a much more impacting contribution to the genetic composition of the flock than females. Therefore, the use of information of males in the evaluation of the variability of a population is of paramount importance. The present study thus proposes to examine the phenotypic diversity of roosters of different genetic groups reared in family farming systems.

\section{Material and Methods}

Research on animals was conducted according to the institutional committee on animal use (case no. 404/17).

The study was conducted with chickens reared in the mid-North region of Brazil. Data were collected only from adult males. Morphological (plumage color, comb type, presence of crest, and ear tucks) and morphometric (lengths, circumferences, and heights of body parts) body traits were measured in four ecotypes and one synthetic group of naturalized birds and also in fighting cocks and in roosters from family farming facilities in the municipalities of Teresina $\left(5^{\circ} 05^{\prime} 21.0^{\prime \prime} \mathrm{S}\right.$ and $42^{\circ} 48^{\prime} 07.0^{\prime \prime} \mathrm{W}$ ) and Campo

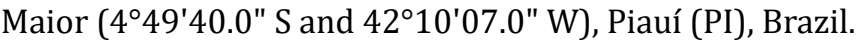

Data collected from the Graúna Dourada, Brejeira, Teresina, and Nordestina ecotypes and the Sertaneja synthetic group were measured in 34, 35, 28, 32, and 10 animals, respectively, located in Teresina.

The family farms were randomly sampled in the rural area of the municipalities of Teresina and Campo Maior, where measurements were taken in 30 and 10 animals, respectively. We also collected data of 106 fighting cocks rescued from fighting in Teresina.

The following qualitative traits were obtained in a visual assessment: plumage color, comb type, eye color, beak color, feet color, presence of crest, presence of naked neck, and presence of feathered feet.

Quantitative traits were measured following the methodology suggested by Francesch et al. (2011) (Table 1). The data were tabulated on electronic spreadsheets for later editing of the work files and statistical analyses.

Qualitative traits were described by frequency analysis. Analysis of variance was applied for the quantitative traits, according to the statistical model below:

$$
Y_{i j k}=\mu+\alpha_{i}+\beta_{j}+(\alpha \beta)_{i j}+e_{i j k^{\prime}}
$$

in which $Y_{i j k}$ is the expected response of the dependent variable, $\mu$ is the population mean, $\alpha_{i}$ is the effect of genetic group $i, \beta_{j}$ is the effect inherent to handler $j,(\alpha \beta)_{i j}$ is the interaction effect between the two factors, and $e_{i j k}$ is the random error. The means of the traits for the model effects were compared with each other using Scott Knott's test $(\mathrm{P}<0.05)$.

To evaluate the phenotypic diversity of the genetic groups, the means of each body morphometric trait and live weight of each genetic group were estimated. Means were subjected to principal component 
Table 1 - Description of body morphometric and morphological traits of chicken breed groups

\begin{tabular}{|c|c|}
\hline Trait & Description of measurement \\
\hline Live weight & Live weight of the bird obtained on the same day the other variables were measured \\
\hline Wingspan & Distance between the extremities of the stretched wings \\
\hline Skull length & Distance from the occipital joint to the insertion of the beak on the skull \\
\hline Skull width & Measured at the eye level \\
\hline Comb length & Distance between the insertion of the comb on the beak to the end of the comb \\
\hline Comb height & Distance from the central point of the beak to the insertion of the comb on the skull \\
\hline Eye length & Distance between the corners of the eyelids in the horizontal direction \\
\hline Eye width & Vertical distance between the corners of the eyelids \\
\hline Beak length & Measured from the beak tip to the insertion of the beak on the skull \\
\hline Beak width & Measured from the insertion of the beak and perpendicularly up to the end of the lower mandible \\
\hline Lobe length & Maximum length, measured while maintaining the head of the bird perpendicular to the neck \\
\hline Lobe width & As in the previous measurement, we measured the second largest dimension \\
\hline Wattle length & From the insertion of the wattle on the beak to the extremity of the wattle \\
\hline Wattle width & Measurement of the second largest dimension of the wattle, perpendicularly to the length \\
\hline Neck length & Distance between the nape and the insertion of the neck on the body \\
\hline Keel length & Distance between both vertices of the sternum \\
\hline Breast circumference & Measured in the portion above the wing \\
\hline Abdominal circumference & Measured in the portion above the drumstick \\
\hline Drumstick length & Anatomically corresponding to the tibiotarsus \\
\hline Thigh length & Anatomically corresponding to the femur \\
\hline Shank length & $\begin{array}{l}\text { Anatomically corresponding to the tarsometatarsal bone in chickens, commonly known as feet } \\
\text { (without the fingers) }\end{array}$ \\
\hline Ventral length & $\begin{array}{l}\text { Measured from the insertion of the neck on the body, along the pectoralis muscle, up to the } \\
\text { coccygeal vertebrae }\end{array}$ \\
\hline Back length & Measured from the insertion of the neck on the body up to the coccygeal vertebrae \\
\hline Body length & Measured from the beak tip to the tip of the middle finger when the bird is lying \\
\hline
\end{tabular}

analysis to estimate the eigenvalues and eigenvectors and then identify the traits that allow for the differentiation between genetic groups.

Next, the means of the traits were standardized by subtracting their average and dividing by the standard deviation. Results were used to calculate the Euclidean distance between genetic groups and were subjected to the Average Linkage (UPGMA) and Ward's (1963) clustering methods and Tocher's optimization method, using R software version 3.4.2 (R Core Team, 2017).

In the cluster analyses using the first two criteria, we calculated the AU (approximately unbiased) values by multiscale bootstrap resampling and BP (bootstrap probability), which is less precise than the $\mathrm{AU}$ value. Clusters with high $\mathrm{AU}$ values (e.g., 95\%) can be considered as strongly supported by the data (Suzuki and Shimodaira, 2006).

The same software was adopted to calculate the cophenetic correlation coefficient to evaluate the consistency of clustering and of the frequency homogeneity analysis of qualitative traits and to calculate the estimates of frequencies, analysis of variance, and Scott Knott's test of means.

\section{Results}

There was no significant interaction between the effects of genetic groups and the handlers who took the measurements. In the evaluation of feathering type, no "naked neck" was observed, and thus full feathering prevailed (Figure 1). 
Dark-colored plumage prevailed among the roosters (Table 2). The Graúna Dourada ecotype showed $100 \%$ black plumage, whereas the Teresina ecotype had $100 \%$ red plumage. Red plumage prevailed in the Brejeira ecotype (42.86\%), while the Nordestina group was distinct from the others for having a higher percentage of animals with light plumage, in which the white color was the most common (50\%). The fighting cocks showed a higher percentage of black $35.85 \%)$ and red $(34.91 \%)$ plumage.

There was a predominance of birds with light eyes and skin, except for the Sertaneja group, the roosters reared in Campo Maior, and the Grauna Dourada ecotype, in which 70, 60, and 52.94\% of the animals were dark-eyed, respectively. It is noteworthy that fighting cocks had a reddish drumstick. In terms of beak color, the Graúna Dourada ecotype roosters showed dark (brown and black) beaks, whereas the other groups had a larger proportion of yellow beak and the Nordestina ecotype had a light-colored beak. Another noteworthy finding was the prevalence of yellow shank with reddish tones.

Lacking crest, presence of ear tuft, naked neck, and feathered shank prevailed in all genetic groups evaluated. The frequency of yellow-pinkish shank was homogenous across the genetic groups.

The single- and pea-type combs were observed in the studied genetic groups. Single combs were found in $100 \%$ of the Graúna Dourada, Nordestina, and Teresina ecotypes and in the synthetic group Sertaneja. Pea-type combs occurred in $100 \%$ of the Brejera animals and fighting cocks. The same type of comb occurred with a greater frequency in the family-farmed animals evaluated in Teresina (96.67\%) and Campo Maior (90\%).
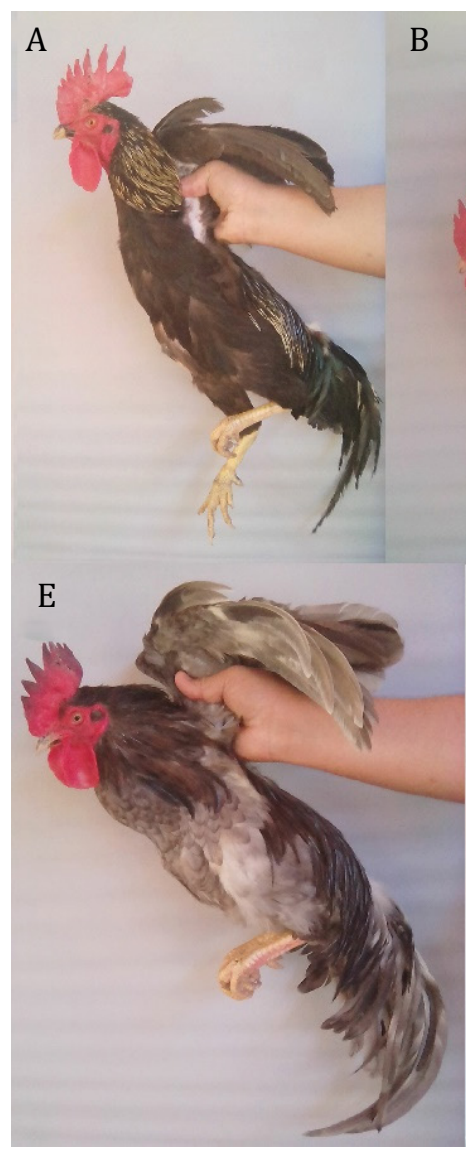

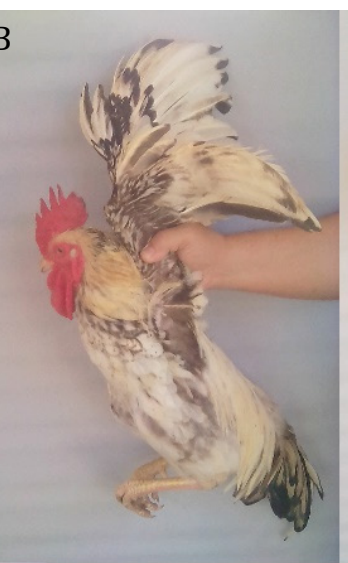

F
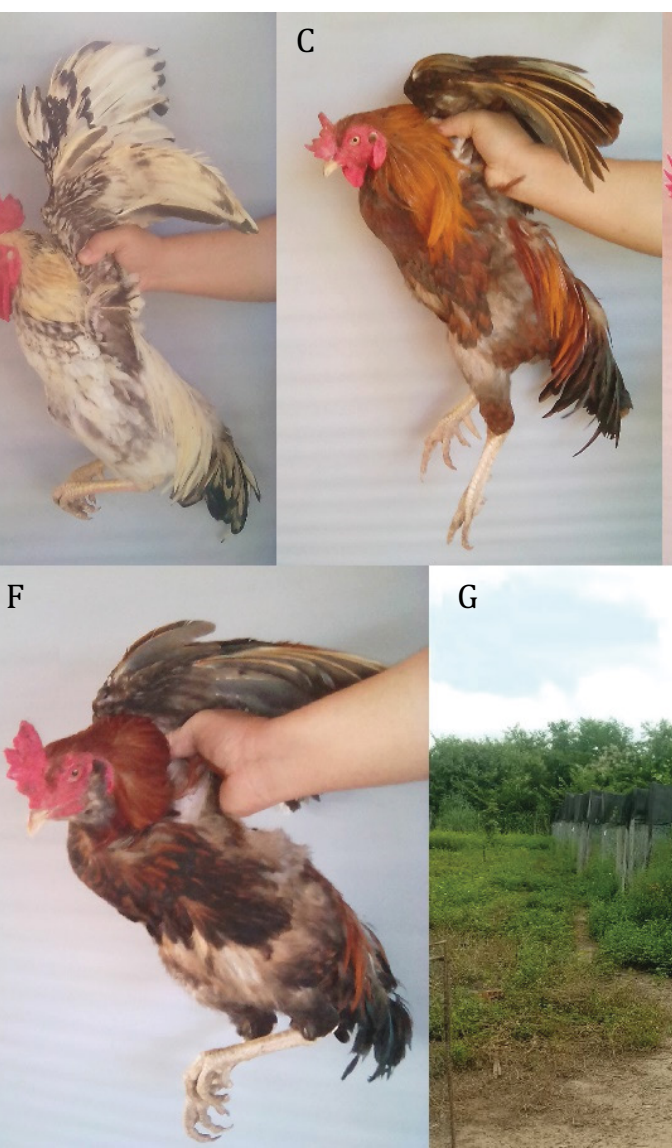

G

D
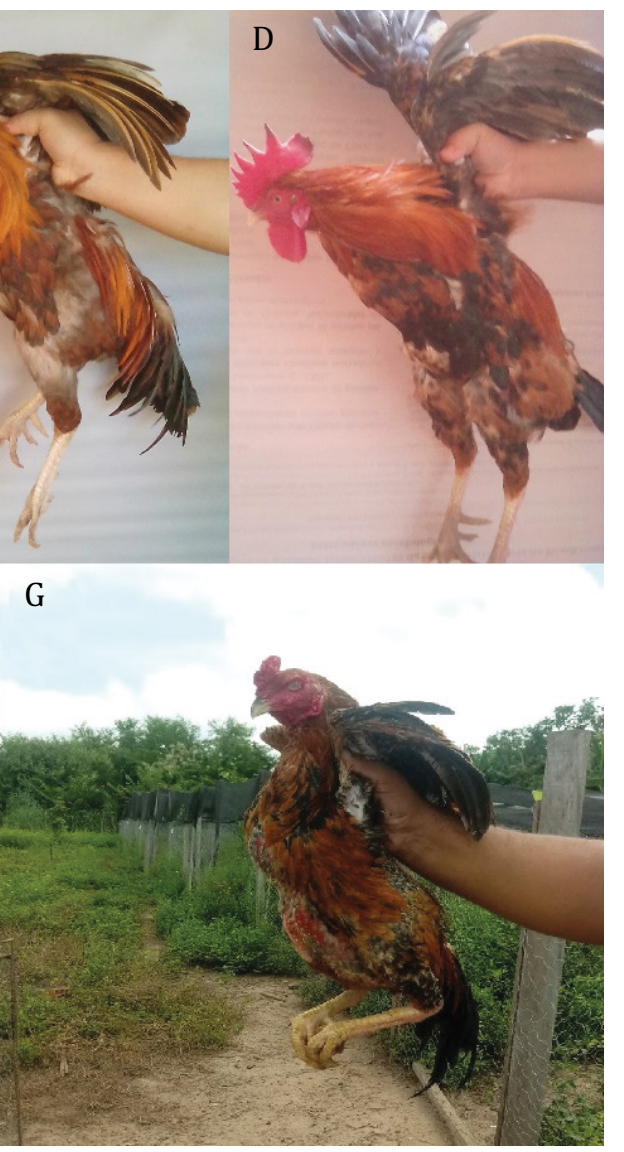

Figure 1 - Photographs of Graúna Dourada (A), Nordestina (B), Brejeira (C), and Teresina (D) ecotype roosters; Sertaneja genetic group rooster (E); family-farmed rooster (F); and fighting cock (G). 
The high coefficient of variation for comb height (60.13\%; Table 3) clearly demonstrates the existence of differences between the comb types present in the roosters of the evaluated groups. The mean value of this trait for those animals was lower and similar to that of the roosters from Teresina.

The highest live weight was obtained by fighting cocks, whose mean values were similar to those of the family-farmed animals. The average live weights of the Graúna Dourada, Nordestina, Brejeira, and Teresina ecotype roosters were $2.309,2.297,2.212$, and $2.404 \mathrm{~kg}$, respectively.

Live weight showed large variations, differing between the evaluated genetic groups. Principal component analysis of the traits (Table 3) showed that the first component explained $97.91 \%$ of the existing variability between genetic groups, and body weight was the trait that most contributed in this component.

Given the elevated percentage variability attributed to the live weight of the animals in the first component and the inexpressive participation of the other traits, in addition to the fact that this trait was influenced by the environment, a second analysis was undertaken excluding body weight. The analysis revealed that the first component explained $80.16 \%$ of the variability present in the groups (Figure 2). Together, the first two components explained $91.47 \%$ of the variability. The traits with the highest percentage variability in the first and in the second components were wingspan and body length.

Figure 3 depicts the dendrograms resulting from the Ward's and Average cluster analyses, which were obtained with the same traits as those of the first principal component analysis.

Table 2 - Qualitative phenotypic traits of roosters of genetic groups reared in mid-Northern Brazil, 2018

\begin{tabular}{|c|c|c|c|c|c|c|c|c|c|c|c|c|c|c|c|c|c|c|}
\hline \multirow[t]{2}{*}{ Trait } & & \multicolumn{2}{|c|}{$\begin{array}{c}\text { Campo } \\
\text { Maior - PI }\end{array}$} & \multicolumn{2}{|c|}{$\begin{array}{l}\text { Teresina } \\
\text { - PI }\end{array}$} & \multicolumn{2}{|c|}{$\begin{array}{l}\text { Fighting } \\
\text { cock }\end{array}$} & \multicolumn{2}{|c|}{$\begin{array}{l}\text { Graúna } \\
\text { Dourada }\end{array}$} & \multicolumn{2}{|c|}{ Nordestina } & \multicolumn{2}{|c|}{ Brejeira } & \multicolumn{2}{|c|}{ Sertaneja } & \multicolumn{2}{|c|}{ Teresina } & \multirow[t]{2}{*}{ P-value } \\
\hline & & $\mathrm{N}$ & $\%$ & $\mathrm{~N}$ & $\%$ & $\mathrm{~N}$ & $\%$ & $\mathrm{~N}$ & $\%$ & $\mathrm{~N}$ & $\%$ & $\mathrm{~N}$ & $\%$ & $\mathrm{~N}$ & $\%$ & $\mathrm{~N}$ & $\%$ & \\
\hline \multirow{8}{*}{$\begin{array}{l}\text { Plumage } \\
\text { color }\end{array}$} & Black & 4 & 40 & 17 & 56.67 & 38 & 35.85 & 34 & 100 & 12 & 37.50 & 4 & 11.43 & - & - & - & - & $2.2 \mathrm{e}-16$ \\
\hline & Maroon & - & - & 1 & 3.33 & 14 & 13.21 & - & - & 1 & 3.13 & - & - & - & - & - & - & ** \\
\hline & Brown & 1 & 10 & - & - & 1 & 0.94 & - & - & 1 & 3.13 & 8 & 22.86 & - & - & - & - & ${ }^{* *}$ \\
\hline & Red & - & - & 1 & 3.33 & 37 & 34.91 & - & - & - & - & 15 & 42.86 & - & - & 28 & 100 & $2.2 \mathrm{e}-16$ \\
\hline & Yellow & 2 & 20 & 1 & 3.33 & 3 & 2.83 & - & - & 1 & 3.13 & 2 & 5.71 & - & - & - & - & ** \\
\hline & Gray & 1 & 10 & 7 & 23.33 & 13 & 12.26 & - & - & 1 & 3.13 & 4 & 11.43 & 8 & 80 & - & - & $2.2 \mathrm{e}-16$ \\
\hline & White & - & - & 1 & 3.33 & - & - & - & - & 16 & 50.00 & 2 & 5.71 & 2 & 20 & - & - & $2.2 \mathrm{e}-16$ \\
\hline & $\begin{array}{l}\text { Black-and-white } \\
\text { pattern }\end{array}$ & 2 & 20 & 2 & 6.67 & - & - & - & - & - & - & - & - & - & - & - & - & $* *$ \\
\hline \multirow{2}{*}{$\begin{array}{l}\text { Comb } \\
\text { type }\end{array}$} & Single & 1 & 10 & 1 & 3.33 & - & - & 34 & 100 & 32 & 100 & - & - & 10 & 100 & 28 & 100 & $2.2 \mathrm{e}-16$ \\
\hline & Pea & 9 & 90 & 29 & 96.67 & 106 & 100 & - & - & - & - & 35 & 100 & - & - & - & - & $2.2 \mathrm{e}-16$ \\
\hline \multirow{3}{*}{$\begin{array}{l}\text { Eye } \\
\text { color }\end{array}$} & Light & 4 & 40 & 27 & 90 & 106 & 100 & 16 & 47.06 & 17 & 53.13 & 23 & 65.71 & 3 & 30 & 19 & 63.86 & $8.8 \mathrm{e}-12$ \\
\hline & Dark & 6 & 60 & 3 & 10 & - & - & 18 & 52.94 & 15 & 46.88 & 12 & 34.29 & 7 & 70 & 9 & 32.14 & $2.2 \mathrm{e}-16$ \\
\hline & Light & 3 & 30 & - & - & 8 & 7.55 & - & - & 14 & 43.75 & 5 & 14.29 & 4 & 40 & 3 & 10.71 & $2.2 \mathrm{e}-16$ \\
\hline \multirow{4}{*}{$\begin{array}{l}\text { Beak } \\
\text { color }\end{array}$} & Yellow & 5 & 50 & 18 & 60 & 69 & 65.09 & - & - & 9 & 28.13 & 22 & 62.86 & - & - & 18 & 64.29 & $2.2 \mathrm{e}-16$ \\
\hline & Brown & 2 & 20 & 12 & 40 & 16 & 15.09 & 31 & 91.18 & 7 & 21.88 & 4 & 11.43 & 4 & 40 & 3 & 10.71 & $2.2 \mathrm{e}-16$ \\
\hline & Black & - & - & - & - & 13 & 12.26 & 3 & 8.82 & 2 & 6.25 & 4 & 11.43 & 2 & 20 & 4 & 14.28 & $5.4 \mathrm{e}-06$ \\
\hline & Light & - & - & - & - & 1 & 0.94 & 1 & 2.94 & 2 & 6.25 & 1 & 2.86 & 1 & 10 & 1 & 3.57 & ** \\
\hline \multirow{3}{*}{$\begin{array}{l}\text { Shank } \\
\text { color }\end{array}$} & Dark & - & - & 6 & 20 & 3 & 2.83 & 8 & 23.53 & 2 & 6.25 & 4 & 11.43 & 1 & 10 & 1 & 3.57 & $1.1 \mathrm{e}-08$ \\
\hline & Yellow & - & - & - & - & - & - & 1 & 2.94 & - & - & 1 & 2.86 & - & - & 1 & 3.57 & ** \\
\hline & Pinkish yellow & 10 & 100 & 24 & 80 & 102 & 96.23 & 24 & 70.59 & 28 & 87.50 & 29 & 82.26 & 8 & 80 & 25 & 89.29 & 0.386 \\
\hline \multirow{2}{*}{$\begin{array}{l}\text { Present } \\
\text { of crest }\end{array}$} & Yes & - & - & 1 & 3.33 & 6 & 5.66 & 9 & 26.47 & 4 & 12.50 & 7 & 20 & 2 & 20 & 6 & 21.43 & $2.8 \mathrm{e}-08$ \\
\hline & No & 10 & 100 & 29 & 96.67 & 100 & 94.34 & 25 & 73.53 & 28 & 87.50 & 28 & 80 & 8 & 80 & 22 & 78.57 & 0.3611 \\
\hline \multirow{2}{*}{$\begin{array}{l}\text { Presence } \\
\text { of ear } \\
\text { tuft }\end{array}$} & Yes & - & - & 2 & 6.67 & 5 & 4.72 & - & - & - & - & - & - & - & - & 5 & 17.86 & ** \\
\hline & No & 10 & 100 & 28 & 93.33 & 101 & 95.28 & 34 & 100 & 32 & 100 & 35 & 100 & 10 & 100 & 23 & 82.14 & 0.8946 \\
\hline
\end{tabular}

$\mathrm{N}$ - number of individuals; \% - percentage of individuals for each trait.

${ }^{*}$ Chi-squared test.

${ }^{* *}$ Test not performed due to incorrect chi-square approximation or insufficient data for the analysis. 
Table 3 - Quantitative traits of genetic groups of roosters reared in mid-Northern Brazil, 2018

\begin{tabular}{|c|c|c|c|c|c|c|c|c|c|c|}
\hline Trait $^{1}$ & $\begin{array}{l}\text { Campo } \\
\text { Maior - PI }\end{array}$ & $\begin{array}{c}\text { Teresina } \\
\text { - PI }\end{array}$ & $\begin{array}{l}\text { Fighting } \\
\text { cock }\end{array}$ & $\begin{array}{c}\text { G. Dourada } \\
\text { ecotype }\end{array}$ & $\begin{array}{l}\text { Nordestina } \\
\text { ecotype }\end{array}$ & $\begin{array}{l}\text { Brejeira } \\
\text { ecotype }\end{array}$ & $\begin{array}{l}\text { Sertaneja } \\
\text { group }\end{array}$ & $\begin{array}{l}\text { Teresina } \\
\text { ecotype }\end{array}$ & SD & CV (\%) \\
\hline Live weight & 2522.0a & 2695.7a & 2957.1a & $2308.6 \mathrm{~b}$ & $2295.6 \mathrm{~b}$ & $2212.1 \mathrm{~b}$ & 1894.3b & $2404.5 b$ & 591.10 & 22.91 \\
\hline Wingspan & $556.0 \mathrm{a}$ & $547.2 \mathrm{a}$ & $485.3 \mathrm{~b}$ & $466.0 \mathrm{~b}$ & $459.7 \mathrm{~b}$ & $477.1 \mathrm{~b}$ & $492.2 \mathrm{~b}$ & $477.1 \mathrm{~b}$ & 59.73 & 12.25 \\
\hline Skull length & $41.1 \mathrm{a}$ & $43.3 \mathrm{a}$ & $38.4 a$ & $42.7 \mathrm{a}$ & $41.8 \mathrm{a}$ & $38.4 a$ & $40.1 \mathrm{a}$ & $40.9 a$ & 6.34 & 15.78 \\
\hline Skull width & $36.1 \mathrm{a}$ & $38.2 a$ & 33.3a & $36.0 \mathrm{a}$ & $36.8 \mathrm{a}$ & $34.7 \mathrm{a}$ & $38.1 \mathrm{a}$ & $38.2 \mathrm{a}$ & 6.95 & 16.99 \\
\hline Comb length & $58.8 \mathrm{c}$ & $40.4 \mathrm{~d}$ & $43.4 d$ & $100.1 \mathrm{a}$ & $90.3 a$ & $73.8 \mathrm{~b}$ & $94.6 \mathrm{a}$ & $100.3 a$ & 30.71 & 46.55 \\
\hline Comb height & $28.6 \mathrm{~b}$ & $19.9 \mathrm{c}$ & $17.0 \mathrm{c}$ & $58.2 \mathrm{a}$ & $56.3 a$ & $35.7 \mathrm{~b}$ & $52.6 \mathrm{a}$ & $61.1 \mathrm{a}$ & 20.99 & 60.13 \\
\hline Eye length & $17.4 \mathrm{a}$ & $17.0 \mathrm{a}$ & $14.9 \mathrm{a}$ & $14.9 \mathrm{a}$ & $15.9 \mathrm{a}$ & $16.3 \mathrm{a}$ & $15.4 \mathrm{a}$ & $16.7 \mathrm{a}$ & 2.56 & 16.35 \\
\hline Eye width & $11.0 \mathrm{a}$ & $12.6 \mathrm{a}$ & $10.9 \mathrm{a}$ & $11.2 \mathrm{a}$ & $12.7 \mathrm{a}$ & $12.5 \mathrm{a}$ & $11.4 \mathrm{a}$ & $12.5 \mathrm{a}$ & 2.26 & 19.31 \\
\hline Beak length & 20.6a & $22.0 \mathrm{a}$ & $23.0 \mathrm{a}$ & $23.2 \mathrm{a}$ & $25.9 \mathrm{a}$ & $23.2 \mathrm{a}$ & $23.3 a$ & $27.0 \mathrm{a}$ & 0.89 & 38.90 \\
\hline Beak width & $10.4 \mathrm{c}$ & $15.6 a$ & $14.6 \mathrm{~b}$ & $14.0 \mathrm{~b}$ & $14.1 \mathrm{~b}$ & $13.7 \mathrm{~b}$ & $14.0 \mathrm{~b}$ & $14.1 \mathrm{~b}$ & 1.67 & 11.70 \\
\hline Lobe length & $10.4 \mathrm{a}$ & $9.8 \mathrm{a}$ & $10.9 \mathrm{a}$ & $11.8 \mathrm{a}$ & $12.2 \mathrm{a}$ & $11.5 a$ & $11.6 \mathrm{a}$ & $12.4 \mathrm{a}$ & 3.68 & 32.71 \\
\hline Lobe width & $7.9 \mathrm{a}$ & $8.2 \mathrm{a}$ & $8.7 \mathrm{a}$ & $9.2 \mathrm{a}$ & $9.1 \mathrm{a}$ & $9.3 a$ & $9.8 \mathrm{a}$ & $9.4 \mathrm{a}$ & 2.23 & 24.94 \\
\hline Wattle length & $27.1 \mathrm{c}$ & $11.7 \mathrm{~d}$ & $0.6 \mathrm{e}$ & $45.8 \mathrm{a}$ & $50.3 a$ & $37.4 \mathrm{~b}$ & $44.2 \mathrm{a}$ & $43.7 \mathrm{a}$ & 22.97 & 95.83 \\
\hline Wattle width & $17.8 \mathrm{~b}$ & $4.7 \mathrm{c}$ & $1.4 \mathrm{c}$ & $46.0 \mathrm{a}$ & $46.1 \mathrm{a}$ & $36.2 \mathrm{a}$ & $44.5 a$ & $42.5 a$ & 22.50 & 100.07 \\
\hline Neck length & $166.5 a$ & $156.2 \mathrm{a}$ & $160.1 \mathrm{a}$ & $138.0 \mathrm{~b}$ & $148.3 b$ & $150.6 \mathrm{~b}$ & $142.5 b$ & $148.3 b$ & 21.71 & 14.19 \\
\hline Keel length & $142.7 \mathrm{a}$ & $140.3 a$ & $151.9 \mathrm{a}$ & $137.9 \mathrm{~b}$ & $144.5 \mathrm{a}$ & $130.0 \mathrm{~b}$ & $131.9 \mathrm{~b}$ & $134.3 b$ & 16.41 & 11.50 \\
\hline $\begin{array}{l}\text { Breast } \\
\text { circumference }\end{array}$ & $343.0 \mathrm{a}$ & $355.8 \mathrm{a}$ & $351.6 a$ & $328.9 b$ & $331.7 \mathrm{~b}$ & $316.3 \mathrm{~b}$ & $320.1 b$ & $334.1 \mathrm{~b}$ & 31.03 & 9.14 \\
\hline $\begin{array}{l}\text { Abdominal } \\
\text { circumference }\end{array}$ & $391.6 a$ & $409.2 \mathrm{a}$ & $391.6 a$ & $369.3 b$ & $357.2 \mathrm{~b}$ & $356.7 \mathrm{~b}$ & $355.0 \mathrm{~b}$ & $369.3 b$ & 43.72 & 11.53 \\
\hline Drumstick length & $163.0 \mathrm{a}$ & $152.6 \mathrm{~b}$ & $162.2 \mathrm{a}$ & $140.3 b$ & $152.3 \mathrm{~b}$ & $156.3 \mathrm{a}$ & $146.2 \mathrm{~b}$ & $149.4 b$ & 17.28 & 11.15 \\
\hline Thigh length & $131.0 \mathrm{a}$ & $129.4 a$ & $126.5 \mathrm{a}$ & $113.4 \mathrm{~b}$ & $115.2 \mathrm{~b}$ & $115.0 \mathrm{~b}$ & $109.5 \mathrm{~b}$ & $115.1 \mathrm{~b}$ & 13.20 & 10.91 \\
\hline Shank length & $125.5 b$ & $121.9 \mathrm{~b}$ & $122.2 b$ & $123.7 \mathrm{~b}$ & $117.5 \mathrm{c}$ & $137.3 \mathrm{a}$ & $117.0 \mathrm{c}$ & $126.4 b$ & 22.25 & 17.94 \\
\hline Ventral length & $322.2 b$ & $359.0 \mathrm{a}$ & $370.9 \mathrm{a}$ & $377.6 \mathrm{a}$ & $357.9 \mathrm{a}$ & $350.5 \mathrm{a}$ & $365.7 \mathrm{a}$ & $369.2 \mathrm{a}$ & 48.61 & 13.34 \\
\hline Back length & $278.0 \mathrm{a}$ & $280.1 \mathrm{a}$ & $294.3 a$ & $257.6 \mathrm{~b}$ & $261.2 b$ & $256.2 b$ & $262.5 b$ & $273.4 \mathrm{a}$ & 29.09 & 10.53 \\
\hline Body length & 787.5a & 747.9a & $820.1 \mathrm{a}$ & $656.3 c$ & $667.8 \mathrm{c}$ & $720.2 b$ & 641.0c & $698.9 b$ & 91.93 & 12.35 \\
\hline
\end{tabular}

SD - standard deviation; CV - coefficient of variation.

${ }^{1}$ Units: weight in grams and morphometric measurements in millimeters.

Means followed by the same letter in the row do not differ significantly according to the Scott Knott test $(\mathrm{P}<0.05)$.

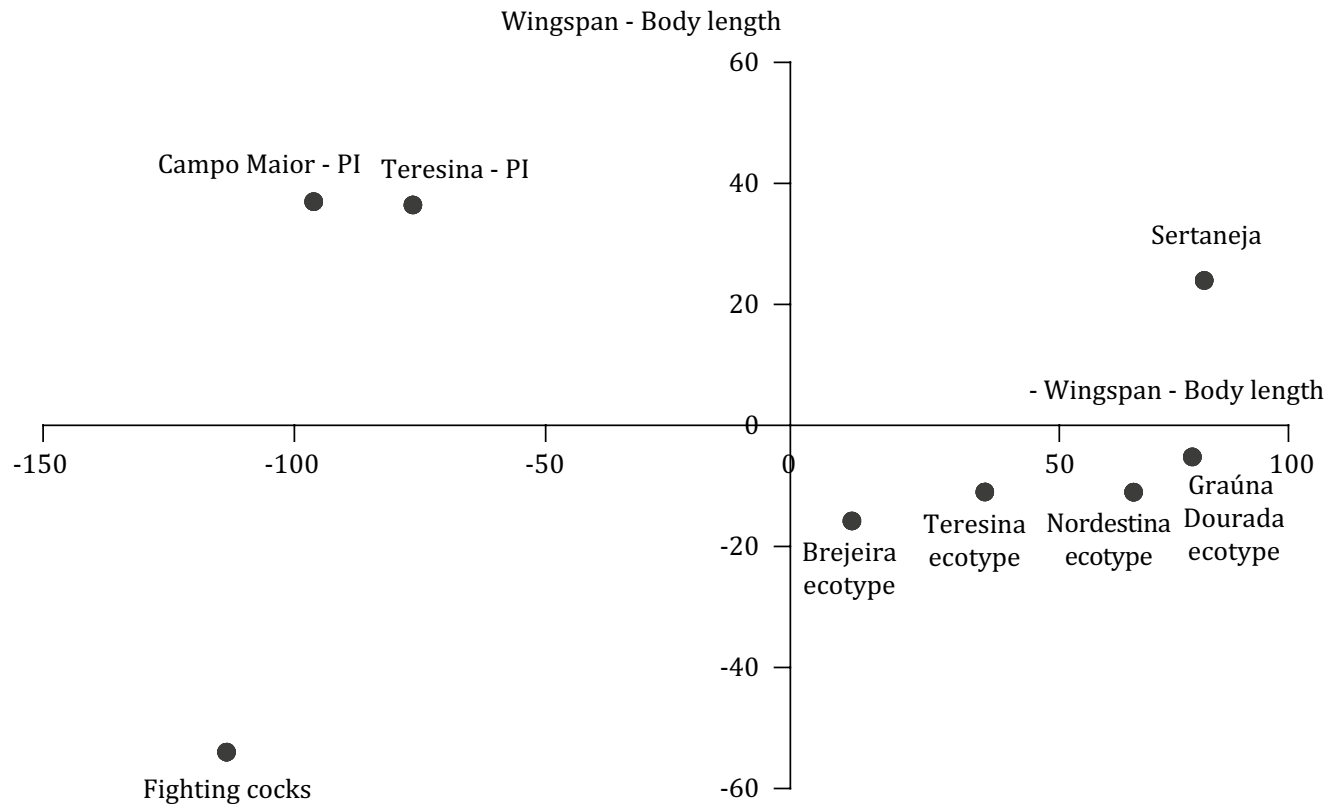

Figure 2 - Scatterplot derived from principal component analysis of fighting cocks and naturalized roosters of the mid-North region of Brazil, 2018. 
A

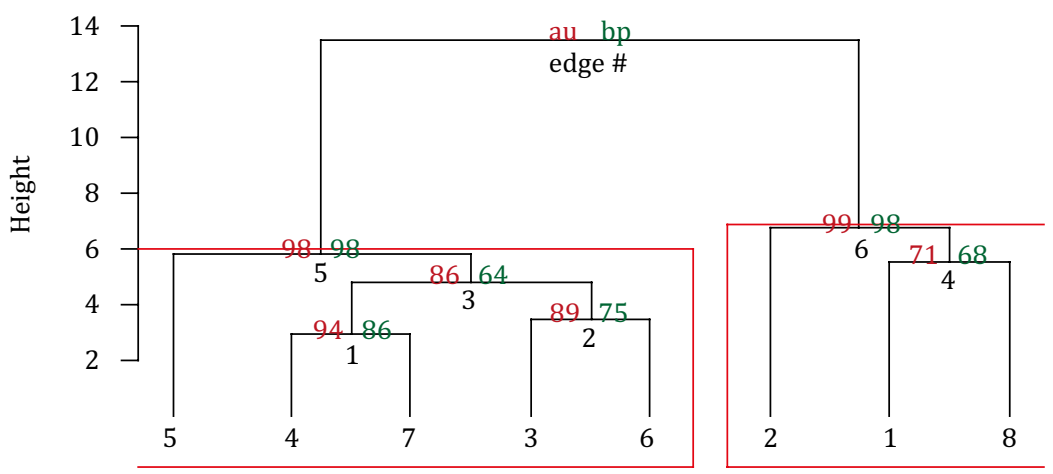

1 - Campo Maior - PI

2 - Fighting cocks

3 - Graúna Dourada ecotype

4 - Nordestina ecotype

5 - Brejeira ecotype

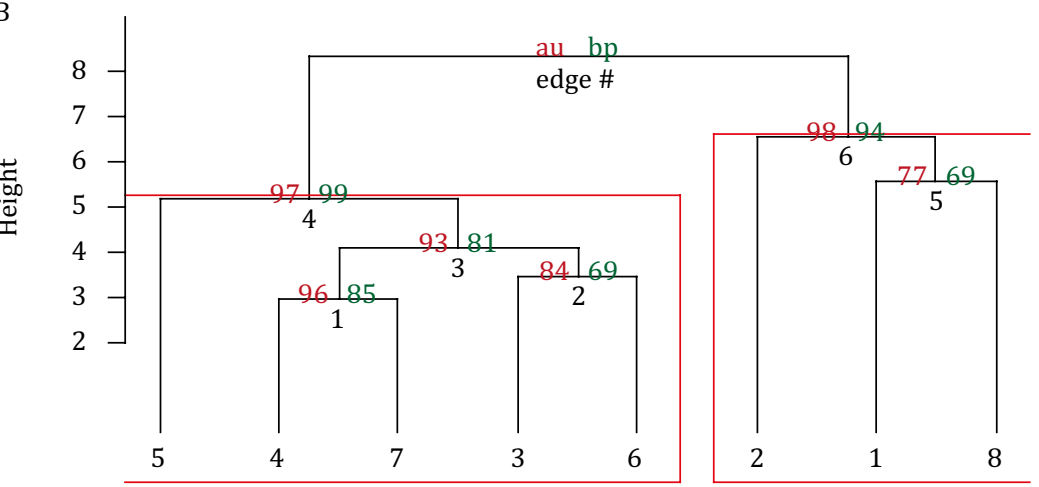

6 - Sertaneja

7 - Teresina ecotype

8 - Teresina - PI

Figure 3 - Dendrograms of phenotypic similarity between fighting cocks, naturalized ecotypes, and roosters from municipalities of mid-Northern Brazil according to Ward's method (Ward, 1963; A) and the Average method (B) and respective approximately unbiased (au) and bootstrap probability (bp) values.

By observing the P-values of $\mathrm{AU}$, we can visualize the animals in two big groups. The first group is composed of the four ecotypes of naturalized chickens and the Sertaneja genetic group, whereas the second contains fighting cocks and family-farmed roosters from Teresina and Campo Maior. A similar finding was obtained when we removed the body weight trait. The qualitative traits showed little variation, which was why they were not included in those analyses.

In this study, cophenetic correlation coefficients of $0.98,0.96$, and 0.95 were estimated according to the Average, Ward's, and Tocher's optimization methods, respectively.

\section{Discussion}

According to Valdés Corrales et al. (2010), single comb and normal feathering are characteristics associated with recessive genes and also with greater ability to adapt to higher environmental temperatures, revealing an adaptive advantage of these animals to climatic adversities.

The prevalence of these colors is similar to what was found in a study of characterization of native birds in Cuba, in which $77.1 \%$ of the studied animals had dark plumage. This plumage tone was associated with the advantage of better camouflage in the presence of predators and with the inexistence of crosses between these populations and commercial strains (Pérez et al., 2004).

The largest number of colors was found in the family-farmed animals, which is similar to the results observed in birds from districts in the mountains in the south of Tanzania, where animals with multi-colored plumage are most frequently found (50.8\%). The other plumages are present in low numbers, such as those composed of the colors black (18.6\%), maroon (9.81\%), white (8.37\%), gray (6.35\%), and red (2.16\%) (Guni and Katule, 2013). 
The lack of feathering on the feet may indicate a lack of influence of Asian ancestors. In this regard, Rodrigues et al. (2006) evaluated fighting animals in Bahia state and confirmed a common ancestry between domestic Brazilian chickens and fighting cocks, which was a product of the cross between Asian and Indian strains.

The phenotypic uniformity for the traits comb type and presence of ear tuft in the naturalized ecotypes may be regarded as an indicator of maintenance of phenotypic identity in those groups, which were evaluated only in a conservation center.

If we consider the type of heritability of the comb type trait, it will not be possible to monitor the occurrence of genetic erosion caused by fighting cocks based on visual analysis. This is due to the random or non-random matings in the Brejeira ecotype, which is the group most similar to the fighting cocks when seen from the side.

The hypothesis of presence of fighting cocks in the composition of animals from the family farms in Teresina and Campo Maior is consistent, given the observed high percentage of animals with a pea-type comb. It should be emphasized that the comb type of the animals from the above-mentioned municipalities might have originated from crosses with strains from other regions.

Another noteworthy fact in this case is that the comb type of the Teresina ecotype does not prevail in those breeding farms, since the group was thus named due to its origins in breeding farms in Teresina, selected from nine birds that showed phenotypic uniformity. This ecotype has been conserved with a view to preserving some originally found traits.

It can thus be assumed that the frequency of occurrence of single comb in birds that had been reared in the region is high. However, because this was not observed, it is possible that matings with fighting cocks had a marked contribution to the frequency of pea-type comb alleles in the two sampled locations as well as alleles of other body traits. In this way, there is a greater possibility of the animals from Teresina and Campo Maior exhibiting similar combs and body characteristics to those of fighting animals or that these animals are potentially strong candidates to cause genetic erosion in extensive breeding flocks of the region.

The presence of cockfighting in the region is expressive, even though it is a non-officially recognized activity. Fighting cocks were brought to Brazil around the year 1530 by Spaniards and quickly spread across the country (Escobar et al., 2014). The aggravating factor from the perspective of regional genetic resource conservation is how they are "discarded" after their useful lifespan as fighting cocks. Their destination is usually family farms, which is the prevalent chicken farming system in the region. Because these roosters are aggressive, they easily impose themselves as the main breeders of the breeding ground, consequently having great potential to cause genetic erosion in the populations of the region.

From the economic standpoint, this is an unfavorable trait in birds, because birds with a small comb tend to have an increase in body temperature caused by a less efficient heat dissipation system, which can interfere negatively with the fertility of breeder chickens (Rosa et al., 2010).

In comparison with other native chickens, live weight values indicate that those ecotypes are classified as medium-sized. This trait has a genetic component but is also greatly influenced by the environment. This result was similar to what occurred with Peloco chickens, a genetic group naturalized in the state of Bahia that showed high phenotypic variability for carcass traits (Almeida et al., 2013; Almeida et al., 2014).

The results obtained with principal component analysis showed the animals distributed into three groups, in the analyses with and without live weight. Fighting cocks were set apart from the others. The second group was formed by family-farmed animals from Teresina and Campo Maior, and the third group consisted of the naturalized ecotypes and the synthetic group Sertaneja. The same result was obtained by cluster analysis using Tocher's optimization method, which showed consistency in the dispersion across the groups visualized in principal component analysis. It can be observed that the 
fighting cocks had the greatest body length and the roosters from Teresina and Campo Maior showed the largest wingspan.

Cophenetic correlation values greater than 0.70 indicate lower distortions in the formed clusters (Sokal and Rohlf, 1962). However, these estimated coefficients close to 1 might have been influenced by the utilized data, since we used the means of groups instead of the individual values of the animals belonging to each genetic group.

The existing similarity between the animals from Teresina and Campo Maior and of the fighting cocks reinforces the affirmation of the presence of those animals in family farms. As observed in loco, because these are aggressive animals, they tend to overpower the present roosters as breeders.

\section{Conclusions}

There is phenotypic variability between the roosters of the genetic groups evaluated by quantitative and qualitative traits. The greater phenotypic similarity between fighting cocks and the animals belonging to family farms in comparison with the evaluated ecotypes may indicate a risk of genetic erosion to which the populations of naturalized chickens are exposed due to the destination of fighting cocks in the region.

\section{Acknowledgments}

The authors thank the Núcleo de Conservação de Galinhas Naturalizadas do Meio-Norte do Brasil (NUGAN-MN), financed by Banco do Nordeste, for the provided data.

\section{Conflict of Interest}

The authors declare no conflict of interest.

\section{Author Contributions}

Conceptualization: V. Ibiapina Neto and F.J.V. Barbosa. Data curation: V. Ibiapina Neto and N.P.S. Santos. Formal analysis: V. Ibiapina Neto and N.P.S. Santos. Funding acquisition: V. Ibiapina Neto and F.J.V. Barbosa. Investigation: V. Ibiapina Neto, F.J.V. Barbosa, J.E.G. Campelo, J.L.R. Sarmento, N.P.S. Santos and M.D.F. Carvalho. Methodology: V. Ibiapina Neto, F.J.V. Barbosa, J.E.G. Campelo, J.L.R. Sarmento, N.P.S. Santos and M.D.F. Carvalho. Project administration: V. Ibiapina Neto and J.E.G. Campelo. Software: V. Ibiapina Neto. Supervision: F.J.V. Barbosa, J.E.G. Campelo, J.L.R. Sarmento, N.P.S. Santos and M.D.F. Carvalho. Validation: F.J.V. Barbosa, J.E.G. Campelo, J.L.R. Sarmento, N.P.S. Santos and M.D.F. Carvalho. Visualization: F.J.V. Barbosa, J.E.G. Campelo, J.L.R. Sarmento, N.P.S. Santos and M.D.F. Carvalho. Writing-original draft: V. Ibiapina Neto. Writing-review \& editing: V. Ibiapina Neto.

\section{References}

Almeida, E. C. J.; Carneiro, P. L. S.; Malhado, C. H. M.; Pereira, A. H. R.; Farias, R. V.; Campos, B. M. and Silva, O. L. 2014. Relative contribution of carcass biometric characteristics phenotypic in diversity among native chickens Peloco and genotypes comercial. Actas Iberoamericanas de Conservación Animal 4:9-11.

Almeida, E. C. J.; Carneiro, P. L. S.; Wenceslau, A. A.; Farias Filho, R. V. and Malhado, C. H. M. 2013. Características de carcaça de galinha naturalizada Peloco comparada a linhagens de frango caipira. Pesquisa Agropecuária Brasileira 48:1517-1523. https://doi.org/10.1590/S0100-204X2013001100013

Clementino, C. S.; Barbosa, F. J. V.; Carvalho, A. M. F.; Costa-Filho, R. A. R.; Silva, G. R.; Campelo, J. E. G.; Britto, F. B. and Diniz, F. M. 2010. Microsatellite DNA loci for population studies in Brazilian chicken ecotypes. International Journal of Poultry Science 9:1100-1106. https://doi.org/10.3923/ijps.2010.1100.1106

Escobar, M. L.; Aguiar, J. O. and Zagui, P. A. 2014. Galos em combate na Paraíba: O descumprimento da legislação ambiental. Revista Direitos Humanos e Democracia 2:143-165. https://doi.org/10.21527/2317-5389.2014.4.143-165 
FAO. 1981. Descriptores de especies avícolas. p.13-15. In: Banco de datos de recursos genéticos animales. Roma, Italia.

Francesch, A.; Villalba, I. and Cartañá, M. 2011. Methodology for morphological characterization of chicken and its application to compare Penedesenca and Empordanesa breeds. Animal Genetic Resources 48:79-84. https://doi.org/10.1017/S2078633610000950

Guni, F. S. and Katule, A. M. 2013. Characterization of local chickens in selected districts of the Southern Highlands of Tanzania: I. Qualitative characters. Livestock Research for Rural Development 25(9).

Méndez, Y.; Pons, A. and Francesch, A. 2011. Comparison of zoometric measurements in Balearic hens. Archivos de Zootecnia 60:445-448. https://doi.org/10.4321/S0004-05922011000300032

Pérez, A.; Polanco, G. and Pérez, Y. 2004. Morphological characteristics of local chicken ecotypes in Villa Clara Province in Central Cuba. Livestock Research for Rural Development 16(10).

R Core Team. 2017. R: A language and environment for statistical computing. R Foundation for Statistical Computing, Vienna, Austria.

Rodrigues, F. P.; Queiroz, S. A. and Duarte, J. M. B. 2006. Genetic relatedness among wild, domestic and Brazilian fighting roosters. Revista Brasileira de Ciência Avícola 8:83-87. https://doi.org/10.1590/S1516-635X2006000200003

Rosa, A. P.; Pilecco, M.; Lucca, W. and Uttpatel, R. 2010. Níveis de cálcio no desempenho de machos reprodutores de corte com e sem crista. Ciência Rural 40:2174-2180. https://doi.org/10.1590/S0103-84782010005000155

Riztyan; Katano, T.; Shimogiri, T.; Kawabe, K. and Okamoto, S. 2011. Genetic diversity and population structure of Indonesian native chickens based on single nucleotide polymorphism markers. Poultry Science 90:2471-2478. https://doi.org/10.3382/ps.2011-01450

Sokal, R. R. and Rohlf, F. J. 1962. The comparison of dendrograms by objective methods. Taxon 11:33-40. https://doi.org/10.2307/1217208

Suzuki, R. and Shimodaira, H. 2006. Pvclust: an R package for assessing the uncertainty in hierarchical clustering. Bioinformatics 22:1540-1542. https://doi.org/10.1093/bioinformatics/btl117

Valdés Corrales, R. J.; Pimentel, O.; Martínez, K. and Ferro, E. M. 2010. Phenotypic characterization of creole poultry genetic basis from San Andrés, Pinar del Río, Cuba. Archivos de Zootecnia 59:597-600.

Ward, J. H. 1963. Hierarchical grouping to optimize an objective function. Journal of the American Statistical Association 58:236-244. https://doi.org/10.1080/01621459.1963.10500845

Zaragoza, M. L.; Rodríguez H., J. V.; Hernández Z., J. S.; Perezgrovas, G. R.; Martínez C., B. and Méndez E., J. A. 2013. Characterization of hens batsi alak in the Highlands of Southeast Mexico. Archivos de Zootecnia 62:321-332. https://doi.org/10.4321/S0004-05922013000300001 